\title{
Fraternity as Cinderella - A Comment on Tu Wei-ming
}

\author{
LEIF LITTRUP
}

Tu Wei-ming's paper reveals much about how East Asia is conceived by East Asians and also by Westerners, and hence provides a good basis for comparisons between East Asian and Euro-American civilizations. " Such comparisons are continuing, reciprocal processes which, hopefully, will lead to a deeper understanding of both the East and the West. The first stage is an understanding of one's own civilization. On the basis of such an understanding we can proceed and attempt to understand other civilizations. This has been the established and more or less articulated procedure in cultural studies ever since their beginnings. The next steps have, perhaps, not been so well established and well articulated. They are, for example here in the West, to use our understanding of the East and, in particular, the Easterners' impression of this understanding together with their understanding of the West, to get a more profound understanding of ourselves. This may again lead to a deeper understanding of the East by both Westerners and Easteners, and so forth. In the following I will attempt to address some aspects of this question.

My point of departure will be some remarks by Benjamin Schwartz of Harvard University who is one of the leading authorities on the history of both East Asian and European thought. In a paper delivered at a conference in Stockholm in May 1988 with the title "Hierarchy, Status, and Authority in Chinese Culture. Some Reflections on Modern Chinese Attitudes," he said among other things:

Having spent some forty years in the society of China scholars it has long been my feeling that one of the most intractable problematic aspects of Chinese culture for most contemporary 
Western scholars has been the perceived role of hierarchy, status, and authority - or to use a harsher 'unmasking' vocabulary, domination, subjugation, and repression - not only in the actual history of Chinese society but even in its shared cultural norms. Most of us are, to a greater or lesser degree, children of the Enlightenment or at least that strain in the Enlightenment which negates and repudiates all ideas and values associated with hierarchy, status, and authority and looks forward to the elimination or drastic reduction of these aspects of 'traditional societies'. This strain of the Enlightenment is shared in disparate ways by the whole host of modern Western socio-political ideologies such as liberalism, Marxism, anarchism, etc. The theoretical dilemmas concerning the relation of liberty, equality, and democracy to each other have by no means been resolved. Yet whether one attacks the concept of authority from the vantage point of individual liberty or of equality - the shared Enlightenment orientations remain. I must myself confess at this point, that to the extent that I myself, accept the generalization that human beings have - on the statistical average - handled hierachy, status, and authority either poorly or not well - I probably also share the Enlightenment bias. ${ }^{2}$ [Emphasis added.]

The crucial words are hierarchy, status, and authority for the East and liberty, equality, and democracy for the West. For the East we can also take a look at the tendencies which, in Tu Wei-ming's words, have been identified for industrial East Asia: the idea of the self as a centre of relationships, a sense of a community of trust modelled on the family, the importance of an established ritual in governing ordinary daily behaviour, the primacy of education as character building, the importance of exemplary leadership in politics, the aversion for civil litigation, the belief in consensus formation, and the practice of self-cultivation; ${ }^{3}$ and we may supplement with the values which in Wm. Theodore de Bary's words have been most emphasized for post-Confucian East Asia: self-discipline, group loyalty, frugality, self-denial, and obedience to authority. ${ }^{4}$ There are differences in the wording but I am not sure 
that there is a great difference in the actual content in the remarks of Schwartz, Tu, and de Bary. Taken together they may, for our purpose, be an adequate description of the main trends in East Asian social thought and behaviour in recent times.

We now turn to Europe and my question is whether or not the words liberty, equality, and democracy, or just liberty and equality, in Professor Schwartz's paper, adequately describe the main trends in European thought and European society since the Enlightenment. I am not an expert in this field but, still, I venture a resounding NO.

In about two months time Paris will go mad with celebrations of the Bicentennial of the Attack on the Bastille on 14 July. In the months and years following this attack in 1789, the political philosophy of the Enlightenment was crystalized into three catchwords Liberté, Egalité, and Fraternité. ${ }^{5}$ Professor Schwartz, in his paper, seems to overlook Fraternity as an important part of European thought and social organization for the last two hundred years. But he is not alone. It appears that virtually everyone else in the West, and also in the East, forgets Fraternity while describing Euro-American civilization. They forget that Euro-American civilizations have within such Fraternities, as well as between them, been able to operate with important concepts such as Hierarchy, Status, Authority, Ritual, Education, Community, Leadership, Reciprocity, and Exclusivity, in addition to Liberty and Equality.

I have been told by experts on France that, in the massive literature which has been published in recent years on the French revolution, Fraternité has received very little attention. ${ }^{6}$ One exception is a book by Marcel David ${ }^{7}$ which has been reviewed in Nouvelle Observateur. ${ }^{8}$ The reviewer talks about Fraternite as the Cinderella of the French Revolution. The two beautiful and wicked sisters were Liberty and Equality. They received the invitation to the ball and the opportunity to attract the attention of the Prince. But they also induced in Cinderella the hopes or dreams which eventually led to the intervention of the Fairy who helped her to dress up for the party. With her practical, diligent, manageable, and restrained character in a beautiful body which fitted into the smallest shoes of the country, she ended on the throne with her prince. Fraternity may likewise, with her practical, diligent, manageable, and restrained character, get the prince, whereas the 
uncontrollable, expansive, and wicked Liberty and Equality may end as unmarried spinsters, or at least without the power and glory of a queen. But without the sisters, the dreams of Cinderella may never have been strong enough to persuade the Fairy to help her, and she would never have married the prince.

The reason for the ostracism of Fraternity in European intellectual history may have been her connection with the more unpleasant aspects of that revolution. As the Jacobins said: "All Frenchmen are now your brothers, until they openly show themselves as traitors to the Motherland."9 The call for Fraternity in the French revolution has also been connected with the call for death (Fraternité ou la Mort) but Professor David has convincingly shown that this is a mistake. Death was the alternative to the acceptance of all the main demands made by the revolution upon the citizens of France such as liberty, equality, and unity and indivisibility of the Republic, as well as fraternity. ${ }^{10}$

Fraternities existed in Europe long before the Revolution. The Christian congregations, and guilds and lodges are among the most obvious examples. The revolutions used, in the spirit of the Enlightenment, Fraternity for the creation of relations between groups that had hitherto been separated by birth, education, trade, or other social forces. This is clear already from the opening of the General Estates on 5 May 1789 when a royal declaration ended with the following words:

Men of all ages, citizens of all ranks, unite your spirits and your hearts so that a solemn engagement will tie you together with all the links of fraternity. ${ }^{11}$

Fraternity was used, both during the National Assembly and later, to create a concord between different groups of society. And in the 1830-revolution the new holders of power emphasized fraternity above liberty and equality "because it was the time of congratulations and for the discovery of each other, no matter what their class relationship was." ${ }^{12}$

In the nineteenth century Fraternities and Brotherhoods were connected with socialist or communist revolutions and manifested themselves in the labour unions of which many still use the terms brother and brotherhood; or fraternities were such dubious 
congregations as the Freemasons and other more or less secret societies.

However, all political, industrial, social, and intellectual leaders in Euro-American societies have participated in some kinds of fraternity. They were (and are?) the public or private bureaucracies, the corps of the military officers, the universities and schools, the clubs and benevolent societies, the clergy and colonial administrations, the families and lineages of the bourgeoisie and the nobility, the stock exchanges and the company boards, etc. etc. Each of these brotherhoods had their rules and hierarchies, and also included many of the tendencies which Professor Tu has listed for industrial East Asia. The concept of modern European capitalism as an expression of individualism or Protestant ethics must, in my opinion, be supplemented by an analysis of the role of the fraternities, if we are to understand what happened in the time of expansion and industrialization. The two beautiful sisters of Liberty and Equality had very important roles, and they may be the offspring of concepts which are specifically Christian or European, but even European man cannot live and function in a world dominated by liberty and equality. Some structures are needed. Boundaries which help to define each human being vis-à-vis himself and others. And in this respect Fraternity is indispensable and may, like Cinderella, end up in the seat of power. ${ }^{13}$

The refusal by the Europeans to realize the role of fraternity in Euro-American society in the nineteenth century is no doubt one of the reasons why the Easterner does not seem to have realized its importance for the understanding of the West. Fraternity is, in this context, normally translated into Chinese as $b o^{\prime} a i^{14}$ which literally means 'universal love'. ${ }^{15}$ Another translation is xiongdi guanxi which literally means 'relationship between brothers' and which perhaps better describes the fraternities which I have tried to depict here. But the 'love across boundaries' is also, as we have seen, part of the concept of fraternity during the Revolution so we can easily understand, and find defensible, the Chinese translation.

Confucian ethics are the self-cultivation of the individual, the extension of the individual from the physical body to the realization of righteousness as an individual in society. Righteousness does not exist in a vacuum of liberty and equality, or in a world with no 
boundaries. She needs fixation points in the world and these are provided in Confucian ethics through the hierarchical structures based upon the five relationships and within the boundaries of what Professor Tu has called fiduciary community (a community of trust) but which I would rather call fraternity.

Every man and woman in both East and West is part of a fraternity from birth, the family. The fraternity of the family is traditionally regarded as stronger in the East than in the West but a final judgement is, in my view, not possible for the time being. Education has, both in the East and in the West, been part of the self-realization of the individual. Here in Denmark we are, for example, very proud of this aspect of education and its role in the modernization of the Danish society, beginning in the second half of the nineteenth century. Education is, furthermore, an admission ticket to fraternities. When looking at education in the East and West now, I find it difficult to decide where its role in character building is most clear. The well known examples of nationalistic or similar indoctrination in some countries are only one part of character building and, perhaps, not the most obvious Confucian part. But in countries with a highly competitive school system, such as the East Asian, education is very clearly the admission ticket to fraternities in further education, private companies, or public bureaucracies.

Fraternities have been a part of the East Asian self-realization for a long time. My suggestion here is that, in this respect, East and West are more alike than we usually assume. But we have preferred to neglect the role of fraternities in the West. From their Cinderella position in the kitchen they have; for a long time, been able to help with the absorbtion of both internal and external changes in European societies without any obvious need to make themselves more visible. It was not until the beginning of this century that such phenomena as the rise of Japan on the Eastern horizon (i.e. the breakdown of the European colonial fraternity), the wars in Europe, and the rise of the working classes might have stimulated a new look at the role of fraternities in and between European societies. But the need to search for such structures was overshadowed by internal developments and the de facto continuity of the importance of Europe in the world during the Cold War. The need has now 
become obvious, and this is perhaps the reason why so many studies of management begin to look to East Asia for inspiration. For here we find the fraternities functioning very successfully, making lots of money, and in political surroundings which do not appear to be too repulsive.

This new interest in the 'Eastern model' raises the question whether or not Confucianism can support the future development in the countries of East Asia and in other parts of the world as well. My answer to that question is Yes and No. Fraternities or, communities of trust, are no doubt essential for the future development, and the time may be ripe when we Euro-Americans also realize the need for some kind of fraternalistic attitude towards ourselves and the rest of the world. I believe this is partly what de Bary talks about when he writes

Lest my own view be misunderstood as a calling for a limiting of intellectual or scientific horizons, the need I see is rather for a better sense of where we stand, of the home base from which we start in reaching out to take on global challenges. Along with an awareness of the new possibilities for learning and growth, and prerequisite to exploring them, we must have a sense of direction, of context, of due process, and of deliberate speed in our use of present resources, both human and physical.

This is no more a conservative view than a liberal one, since being conservative as to means does not preclude liberal ends and may indeed be the only practical way to advance them. Nor does it ignore the possibility that real and present dangers to basic human values may even, in some circumstances, call for prophetic vision or radical action. Such options would exist even in circumstances recognized as severely limiting, just as within the limited horizons of the Confucian world there were both liberal and conservative tendencies, both scholarly and prophetic voices. It does, however, mean accepting the idea that freedom may be found elsewhere than in recourse to a great liberality of means, the exploitation of material resources, or the conquest of space. The discovery of true freedom and creativity comes only in 
limiting contexts, when all are compelled to draw more deeply on inner resources of the human spirit. Indeed, do we not already witness such liberating possibilities in the current popularity of the traditional arts of Asia, whether martial, cultural, or contemplative, the challenge of which is precisely to self-mastery and deeper spiritual creativity in clearly defined contexts?

Similarly in the social order, a more truly open and cosmopolitan - or I should say planetary - outlook might require a more Confucian view of our primary responsibilities. It would have to consider whether our most deep-seated problem in a world of rapid and almost compulsive change may not be the lack of any parochial loyalties in the sense of a responsibility to any given human or earth community. What we need is not a new world to conquer, star wars and all that, but a new parochialism of the earth or planet. This should start, as the Confucians did, with self-reflection and self-restraint. Conscious of the interrelatedness of all things, and of one's own place in an interdependent world, this view should develop a sense of equal responsibility for oneself and others and of reciprocal support for a life-sustaining environment. ${ }^{16}$

Historical evidence may, however, tell us that societies which are based upon a cosmology of fraternity may either be immobilized by this cosmology such as the East apparently was for many centuries or, if external factors push the fraternities into Limbo, then the result may be violent atrocities. A look at the history of both the East and the West in this century suggests to me that there may be such a correspondence.

In the Eastern model, the self-realization of the personality is within the fraternity, and both history and nature are made to serve this fraternity, to regulate the world (jingshi). I believe that this is to some extent also true for the West and may have been dominant in the Middle Ages. The West had, however, the instrument to liberate the self-realization of the individual from the fraternity. The individual could mirror himself in God, or Jesus Christ, and by transferring the love of the fellow human beings to the love of the 
deities, he could obtain some form of self-realization as an individual in society without depending on the fraternity (or sorority).

Western Man could, in the Renaissance, free himself from the community of trust and, consequently, he could make history and nature serve other purposes than the regulation of the fraternity. ${ }^{17}$ I believe this is where we see the two wicked sisters of Liberty and Equality appear on the scene. They opened new horizons to the Cinderellas of the fraternities, and they created a new world with new hopes for Man. But it was not a world which Man could live in for a long time. He needed to resort once again to Fraternity. This Fraternity was not the Cinderella with the narrow outlook from the kitchen. She was the victorious Cinderella who got into the driver's seat on the throne and next to the Prince but, apparently for a long time, invisible to the rest of the world.

In the East, the structures of fraternities were not broken from within but from without, first by the gunboats of the nineteenth century, and later by encouragements to modernize and the opportunities to restructure economic and political life. I suggested earlier that fraternities which are pushed around by external forces and which do not possess the capability for internal adjustments, may be in danger of over-reaction. We should bear this in mind when we look at the possible development of the post-Confucian state in East Asia and the eventual spread of 'the Confucian Way' to the rest of the world. I am sure that the East has something to contribute by way of conceptualizing about the communities of trust, or fraternities, and to make them more a part of our daily life. But I am also sure that the East has something to learn from the West: the liberation of Man from the fraternity, and the procreation of wicked and beautiful sisters who will always induce in Cinderella the strong wish to get from the Kitchen to the Palace.

Leif Littrup is Associate Professor, East Asian Institute and presently Research Fellow in the Center for Research in the Humanities, University of Copenhagen. 


\section{NOTES}

1 This comment is a revised version of my contribution as discussant to Tu Wei-ming's paper "Cultural and Social Dimensions of the Development Process in East Asia: The Role of Confucianism" which was presented in May 1989 in the lecture series "Economic, Political, and Cultural Aspects of the East Asian Modernization Process": and subsequently published in a revised form in Copenhagen Papers in East and Southeast Asian Studies, No. 4, 1989, pp. 81-97.

2 Benjamin Schwartz, "Hierarchy, Status, and Authority in Chinese Culture. Some Reflections on Modern Chinese Attitudes." Paper delivered at the conference "Culture and State in East Asia," Stockholm, May 16-18, 1988.

3 Tu Wei-ming, "A Confucian Perspective on the Rise of industrial East Asia," Bulletin of the American Academy of Arts and Sciences, Vol. XLII, No. 1 (October 1988), p. 35.

$4 \mathrm{Wm}$. Theodore de Bary, East Asian Civilizations: A Dialogue in Five Stages (Cambridge Mass.: Harvard University Press 1988)

5 It was not until the 1848 revolution in France that they began to form a virtually indivisible trinity.

6 Professor John Petersen and Dr. Hans Boll-Johansen of the University of Copenhagen have kindly conveyed their personal impressions to me. Professor Petersen also provided the bibliographical reference.

7 Marcel David, Fraternite et Revolution française (Paris: Aubier, 1987).

8 Mona Ozouf, "Review: Marcel David, Fraternité et Revolution francaise," Nouvelle Observateur, No. 47, 1987.

9 "Tout Francais est aujourd'hui votre frère, JUSQU'A ce qu'il se montre ouvertement traître à la patrie." Ibid.

10 David, Fraternité et Révolution francaise, pp. 167-186;276.

11 "Hommes de tous les âges, citoyens de tous les ordres, unissez vos esprits et vos coers et qu'un engage- ment solennel vous lie de tous les noeds de la fraternité." Ibid., p. 44

12 lbid., p. 280.

13 Marcel David writes about the 1848 revolution that reform projects were carried out which, in respect of social relations, would make it possible for fraternity to ease the incompatibility between liberty and equality, and he writes further that in a Manual for Republic Man and Citizen the duty of fraternity is described as to "unite and reconcile" liberty and equality. See ibid., p. 282.

14 Liberté, égalité et fraternité is translated into Chinese as ziyou, pingdeng, bo'ai. See Zhang Zhilian, "Faguo tongshi xuyan" (Preface to A general history of France), in Zhang Zhilian, Cong Gaolu Dai Gaole (From Gaul to de Gaulle) (Beijing: Sanlian Shuju, 1988), pp. 15-20.

15 The word bo'ai is in the standard dictionaries explained by a quotation from Han $\mathrm{Yu}$ (768-824 A.D.) who equate it with the Confucian concept of ren which means benevolence, humanity, human-heartednes, etc. As a word used by the Confucians it may carry connotations of hierarchy and exclusiveness and that idea has been expressed in discussion with Chinese scholars but others simply equates it with with universal, unrestricted, and all-embracing love. There is a good chance that most Chinese give it that meaning.

16 de Bary, East Asian Civilizations: $A$ Dialogue in Five Stages, pp. 126-127.

17 The point is elaborated in a small article by Professor Wu Yujin of Wuhan University who is one of the leading Chinese specialists on the history of the European Renaissance: See Wu Yujin, "Yin yuanshi zhi guang, zhao gulao shixue zhi diantang - Ouzhou jindai shixue shi du hou" (To illuminate the old hall of historical studies by the light of a distant room - after reading the history of historical studies in Europe), in Shijie Lishi, No. 3, 1986, pp. 19-22. 